\title{
Employability: Does University-Industry Linkages Matters?
}

\author{
Ambreen Gul, Bilal A. Abbasi, Aslan A. Senin
}

\begin{abstract}
This study is aimed at identifying the important university-industry linkages (UILs) activities that can be pivotal in developing self-perceived employability among Pakistani university students. It also examines the relationship between UILs and self-perceived employability. It seeks to answer the question, whether the dimensions of UILs plays any role in selfperceived employability among Pakistani university students?

Design/Methodology/Approach:

The instrument developed by Ishengoma, and Vaaland (2016) was used to identify the important UILs activities and selfperceived employability among students was measured through Rothwell, Herbert, \& Rothwell (2008)' scale. A sample of 285 university students who are enrolled in 11 federally chartered universities of Islamabad, Pakistan was surveyed via close ended questionnaire through emails and in person. Descriptive statistics and PLS-SEM were applied to tests the hypothesized relationship by using SmartPLS.

Finding:
\end{abstract}

The study results reveal that all three dimensions of UILs (1. collaborative training \& educational activities, 2. collaborative consulting activities, 3. collaborative research activities) are positively related to self-perceived employability, and hence, supports all three hypotheses. The strong and significant regression results are indicative of this conjecture. The study also reflects the student internship programs and joint projects

Implications:

The research findings augment our understanding of UILs in Pakistan and how they relate to self-perceived employability. The study findings have implications for universities who are striving for better role in society and for industry, who want to be innovative in order to remain competitive. Lastly it has special implications for students who are about to enter in their professional lives and for policy makers to redefining the role of universities, industry and government to promote employability.

Originality/value:

This research adds values to existing literature on UILs, as most is a unique explanatory study which relates UILs with employability, particularly in context of a developing country

Keywords: University-Industry Linkages, Employability, Developing Countries.

\section{INTRODUCTION}

Employment is not merely a source of livelihood; it also provides an individual with an identity and sense of gratification. Employability is often simply connoted with "getting a job" and erroneously interchange with term

Revised Manuscript Received on April 19, 2019.

Ambreen Gul, Faculty of Management, UTM, Johor Bahru, Malaysia,(email: itsmeambreen@gmail.com)

Bilal A. Abbasi, Faculty of Management, UTM, Johor Bahru, Malaysia, (email :itsmeabbasi@gmail.com)

Aslan A. Senin, Faculty of Management, UTM, Johor Bahru, Malaysia,( email: aslan@utm.my). are most popular UILs activity in Pakistani universities. of previous UILs are descriptive and exploratory in nature. This

employment (Copps \& Plimmer, 2013). "Employability is having a set of skills, knowledge, understanding and personal attributes that make a person more likely to choose and secure occupations in which they can be satisfied and successful" (Dacre Pool, \& Sewell, 2007). Employability is not a new phenomenon but trending downsizing and layoffs due to economic slowdowns (Ngoma, \& Dithan Ntale, 2016) and technology driven skill obsolescence (Clark, 2017; Kennedy\& King, 2005; Loon\& Casimir, 2008), brought it back to limelight (Bargsted, 2017). Particularly, developing countries are facing such challenge of employability (Vaaland, Vaaland, Ishengoma, \& Ishengoma, 2016). Highly educated people are unemployable (Pinto, \& Ramalheira, 2017) and graduate unemployment is on rising trend (Jackson, \& Wilton, 2017). Such situation indicates a deficiency of competitive skills desired by labour market (Ishengoma, \& Vaaland, 2016). Graduate employability domain is right forum to address this challenge (Batistic, \& Tymon, 2017). It is old but still dicey term due to nonclarity of conceptual definition (Pegg, Waldock, HendyIsaac, \& Lawton, 2012). Yorke (2006) defines it as "a set of achievements skills, understandings and personal attributes - that makes graduates more likely to gain employment and be successful in their chosen occupations, which benefits themselves, the workforce, the community and the economy". Coping with ever rising expectations of the industry in terms of training and education of students, is a major graduate employability challenge faced by educational institutions, considering their limited resources (Ishengoma, \& Vaaland, 2016). Such situation calls for partnerships among universities and industries in order bridge skills gap and resource deficiency. Many universities in developing economy have established collaborative arrangements with the industry to meet their obligation of providing relevant education and skills. Such arrangements are termed as university-industry linkages (UILs).

UILs are defined as interactions between all parts of the higher educational system and industrializing economy (Ankrah, Burgess, Grimshaw, \& Shaw, 2013). Collaboration among universities, industries and society is fundamental to improved economic development (Hansen \& Lehmann, 2006; Feng et al., 2011). In order to be competitive in today's globalized economies, the new education and training must be flexible, adaptive and innovate (Filippetti, \& Savona, 2017). UILs provide opportunities to the students and academic staff to interact with industry and get to know the latest competency profile required to get a job and excel 
in it. Studies measuring the impact of UILs on economic development were mainly carried out in a highly industrialized or relatively advanced countries (Alpert, Heaney, \& Kuhn, 2009; Perkmann et al., 2011), where universities have enough physical and human resources (Ankrah et al., 2013). In contrast, in developing countries like Pakistan there weak learning and research infrastructure, limited skilled personnel and insufficient research funds (Ashraf, et al., 2018). In pursuit of fulfilling their obligations and to respond to the government policies, many universities in Pakistan have initiated UILs by pouring their scare resources. Now question is, are these initiatives paying back the dividends inform of higher employability among the graduates? This research paper seeks to answer this question by measuring the impact of UILs on selfperceived employability of the graduates. Measuring employability objectively i.e. number of graduates who secured full times jobs within six months of graduation, has conceptual issues (employability vs employment), and measurement issues as over a time span of six months, external factor contaminate the causal relationship between UIL and employability. Hence, in this paper used selfperceived employability as immediate outcome of UILs.

\section{LITERATURE REVIEW}

The table 1 enlists the studies which were examined during literature review followed by synthesis thereon.

\begin{tabular}{llll}
\multicolumn{1}{c}{$\mathrm{S}$} & Topic / List of Studies \\
r. Themess & & \\
No. & &
\end{tabular}

1 Graduate Hillage and Pollard (1998); Bennett, Employability: Dunne, and Carre (1999); Yorke and Frameworks / Knight (2002); Dacre Pool, and Sewell Models (2007); Bridgstock (2009); Copps and Plimmer (2013); Hogan, ChamorroPremuzic, and Kaiser (2013)

2 Graduate Pinto and Ramalheira (2017); Yang, Employability: Cheung, and Song (2016); Ishengoma and Empirical Vaaland (2016); Hetty van Emmerik, Studies Schreurs, De Cuyper, Jawahar, and Peeters (2012); Cuyper, Bernhard-Oettel, Berntson, Witte, and Alarco (2008); Jackson (2015) Finch, Hamilton, Baldwin, and Zehner (2013); Bell (2016); Ngoma, and Dithan Ntale (2016); Dacre Pool, and Qualter, (2013); Tomlinson (2008) McArdle, Waters, Briscoe, and Hall (2007); Eby, Butts, and Lockwood (2003)
3 UniversityIndustry Linkages (UILs)

The literature review on theoretical frameworks of employability (Sr. No. 01) has highlighted some trends. First, there is no clear consensus about a holistic employability framework. Second, these employability models are only theoretical in nature. Third, most them lacks in empirical research support. Fourth, they do not provide with operationalization mechanism. Lastly, there are two commonalities in all models (1) employment assets (different forms of skills, knowledge, and understanding) and (2) deployment (methods to use these employment assets). Hence, it can be inferred that there are two routes graduate employability; (1) competence-based approach and (2) disposition-based approach.

Similarly, the empirical studies on graduate employability reported at Sr. No. 02, provide evidence that all of them were carried out in developed parts of the world. Only the study of Ngoma and Dithan Ntale (2016) was carried out in Uganda. It reflects insensitivity of the developing world towards soaring issue of graduate employability. Despite the fact that they are the first victims of such trolling unemployability of graduates. Pakistan, where, the present research endeavor is being carried out, is not different from their other developing counterparts. There is hardly any attempt to objectively measure the employability of Pakistani graduates. Secondly, the above review of empirical studies reflects that many factors associated with employability were investigated but the employability has never been studied as an outcome of UILs, except one, of Ishengoma and Vaaland (2016), which solely do not investigate students' perceived employability. In other words, the role of UILs in perceived graduate employability is yet to unfold. The present study exclusively focused on investigating the role of UILs in employability among Pakistani university students. Lastly, the number of "focused" empirical studies related to employability is far less than position papers, proposing employability models. These models are complex, difficult to practice and lacks in research evidence. 
The review of UILs at Sr. No. 03 reveals certain trends; first, the empirical studies are on the rise. They are growing in numbers, it connotes the growing interest of researchers in measuring the university industry linkages in terms of frequency, intensity, and efficiency. Precisely, they are keen to quantify the impact of UILs, as the studies, which were carried out in last two decades are mainly descriptive and exploratory in nature. Such studies primarily focus on nature, type, and characteristics of UILs. Secondly, UILs studies are from 'scientific endogamy', that is, they belong to the research area of science, innovation, and technology. It is rare to find out an investigation from a humanity discipline. Thirdly, topics like 'academic spin offs', 'scientific and technological policies' and 'knowledge transfer channels' are losing the interest of the researchers. Fourthly, researchers are keen to explore the 'characteristics of universities, firms, and scientists', together with 'regional spillovers'. The 'measures and indicators' to operationalize UILs is an emergent topic, as it is important to causation. Fifthly, the explanatory studies measure the cause and effect relationship. In above 15 explanatory studies following dependent variables (effect of UILs) were explored: innovation, trust, international involvement, global configuration, governance, patent value, quality of research, commercialization, and economic growth and development. No one has measured the impact of UILs on perceived graduate employability (the dependent variable of the present study), except one of Ishengoma and Vaaland (2016), which also do not exclusively focus on the perceived employability of graduates. Similarly, the independent variables, which cause in UILs in above studies include Geographic distance and organizational proximity, institutional proximity, social proximity, university prestige, and communication. Lastly, the studies exploring the benefits and motivations for University-Industry Linkages are also evaporating, as their importance is obvious to the world. Similarly, the barriers to UILs are much known and further exploration seems unattractive.

Based on above-mentioned gaps following hypothesis are set for testing

H1. Collaborative training and education activities have a direct and positive effect on the perceived employability of the graduates.

$\boldsymbol{H}$ 2. Collaborative services and consulting activities have a direct and positive effect on the perceived employability of the graduates.

H3. Collaborative research activities have a direct and positive effect on the perceived employability of the graduates.

\section{METHODOLOGY}

All university students who are enrolled in 11 federally chartered universities of Islamabad, Pakistan constituted the population for the study. Convenience sampling technique was used to select the study subjects from the population. Primary data were collected from 285 students. The response level was 81 percent, as out of 350 circulated questionnaires only 285 questionnaires were deposited back to the research team in completed and accurate form.

To find out the impact of UILs activities on perceived graduated employability, we have adapted the UILs and perceived graduate employability instruments of Ishengoma, and Vaaland (2016) and Rothwell, Herbert, \& Rothwell (2008), respectively. The reliability and validity of the instruments through testing the measurement model of the study in SmartPLS. Structural education modelling techniques is used to tests the hypothesized relationship by using SmartPLS.

\section{DATA ANALYSIS AND RESULTS}

The picture 4.1 presents a pectoral summary of the structural and measurement model testing. At the first stage, the adequacy of the measurement model/outer model was assessed. Whereas, the second stage (structural model/inner model) accounts for the recursive relationships (paths) among the latent constructs. A measurement model/outer model gauges the unidirectional predictive relationship between the indicators and their respective constructs. This relationship is evaluated through the assessment of reliability and validity of the constructs. The significant factor loadings having a t-value of well above threshold $\mathrm{t}$ vale $( \pm 1.96)$. This is an indication that items are measuring the right construct and hold well together to do so. Structural model is the second stage of SEM, where hypotheses of the study are tested to explore the causal relationship among the constructs. The estimates that explains the hypothesized relationships among the constructs of a structural model, are called path coefficients. A significant path coefficient indicates a significant relationship between variables. The bootstrapping procedure calculated t-values and p-values, and confidence intervals (Hair et al., 2016). Based on these values, the significance of each relationships was established (Hair et al., 2017). Picture 4.1shows path coefficients and corresponding t-values hypothesized relationships. All the structural paths connecting exogenous constructs with endogenous construct, indicate that each exogenous construct: education and training $(\mathrm{t}=5.492)$ consulting and service $(\mathrm{t}=7.145)$ and research $(\mathrm{t}=4.205)$, significantly effects endogenous construct (perceived graduate employability). Hence, all the three hypotheses (H1, H2, H3) were got accepted. The last step in the assessment of a structural model is to examine the coefficient of determination $\left(\mathrm{R}^{2}\right)$. It is the most commonly used measure to evaluate the structural model. $\mathrm{R}^{2}$ value shows the predictive accuracy of the model (Rigdon, 2014). $\mathrm{R}^{2}$ value reflects the cumulative effects of exogenous latent variables on the endogenous latent variable. That is, the change/variance in endogenous variable due to one unit change in the exogenous variables (Hair et al., 2016). In our case the one unit change in independent variable will bring a 0.610 change in dependent variable. 


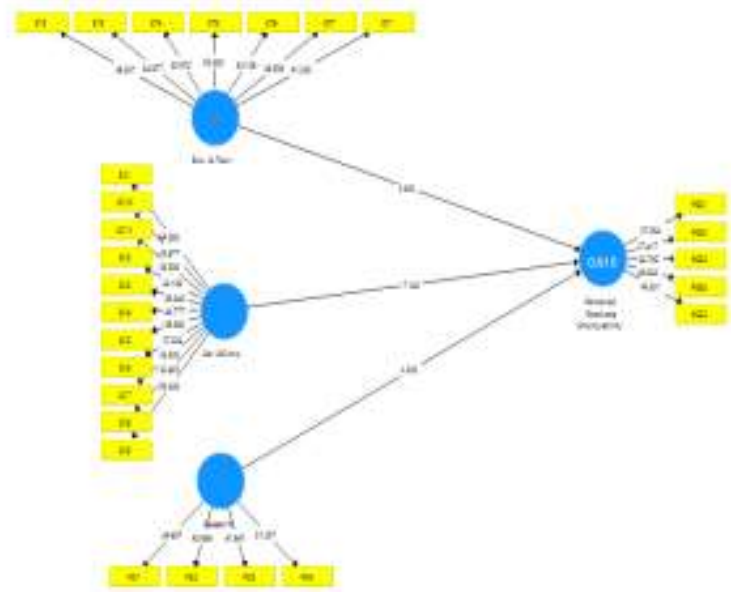

\section{CONCLUSION}

From the results, it is evident that the all three components of UILs (1. education and training, 2. consulting and service, 3 . research activities) has significant effects on perceived graduate employability of the graduates. It means if there will be a high level of UILs activities at an institution, the students of that institutions will be more employable. Because the UILs activities provides them with occupational competence and disposition, which in makes these graduates a hot commodity in jobs market. Our study shows that through enhanced UILs activities developing countries like Pakistan can improve the skill set of its graduates, which in turn can help to lower the soaring graduate unemployment. The study findings have implications for the managers, which they can apply in their respective jurisdictions. The managers of educational institutions, industries, regulatory bodies, and relevant government departments can benefit from the study findings.

\section{REFERENCES}

1. Alpert, F., Heaney, J. G., \& Kuhn, K. A. L. (2009). Internships in marketing: Goals, structures and assessment-Student, company and academic perspectives. Australasian Marketing Journal (AMJ), 17(1), 36-45.

2. Ankrah, S. N., Burgess, T. F., Grimshaw, P., \& Shaw, N. E. (2013). Asking both university and industry actors about their engagement in knowledge transfer: What single-group studies of motives omit. Technovation, 33(2), 50-65.

3. Bargsted, M. (2017). Impact of personal competencies and market value of type of occupation over objective employability and perceived career opportunities of young professionals. Revista de Psicología del Trabajo y

4. Bell, R. (2016). Unpacking the link between entrepreneurialism and employability: An assessment of the relationship between entrepreneurial attitudes and likelihood of graduate employment in a professional field. Education+ Training, 58(1), 2-17.

5. Bennett, N., Dunne, E., \& Carré, C. (1999). Patterns of core and generic skill provision in higher education. Higher education, 37(1), 71-93.

6. Bridgstock, R. (2009). The graduate attributes we've overlooked: Enhancing graduate employability through career management skills. Higher Education Research \& Development, 28(1), 31-44. de las Organizaciones.

7. Casper, S. (2013). The spill-over theory reversed: The impact of regional economies on the commercialization of university science. Research Policy, 42(8), 1313-1324.

8. Clarke, M. (2017). Rethinking graduate employability: the role of capital, individual attributes and context. Studies in Higher Education, 1-15.

9. Copps, J., \& Plimmer, D. (2013). Inspiring impact-The journey to employment: A guide to understanding and measuring what matters for young people.

10. Cuyper, N. D., Bernhard-Oettel, C., Berntson, E., Witte, H. D., \& Alarco, B. (2008). Employability and employees' well-being: Mediation by job insecurity. Applied Psychology, 57(3), 488-509.

11. Dacre Pool, L., \& Qualter, P. (2013). Emotional selfefficacy, graduate employability, and career satisfaction: Testing the associations. Australian Journal of Psychology, 65(4), 214-223.

12. Dacre Pool, L., \& Sewell, P. (2007). The key to employability: developing a practical model of graduate employability. Education+ Training, 49(4), 277-289.

13. Eby, L. T., Butts, M., \& Lockwood, A. (2003). Predictors of success in the era of the boundaryless career. Journal of organizational behavior, 24(6), 689-708.

14. Feng, Y., Broder, C. C., Kennedy, P. E., \& Berger, E. A. (2011). HIV-1 entry cofactor: functional cDNA cloning of a seven-transmembrane, $\mathrm{G}$ protein-coupled receptor. Journal of immunology (Baltimore, Md.: 1950), 186(11), 6076.

15. Kennedy, P. W., \& King, I. P. (2005). Economic progress and skill obsolescence with network effects. Economic Theory, 26(1), 177-201.

16. Loon, M., \& Casimir, G. (2008). Job-demand for learning and job-related learning: The moderating effect of need for achievement. Journal of Managerial Psychology, 23(1), 89-102.

17. Filippetti, A., \& Savona, M. (2017). University-industry linkages and academic engagements: individual behaviours and firms' barriers. Introduction to the special section. The Journal of Technology Transfer, 1-11.

18. Finch, D. J., Hamilton, L. K., Baldwin, R., \& Zehner, M. (2013). An exploratory study of factors affecting undergraduate employability. Education+ Training, 55(7), 681-704.

19. Frasquet, M., Calderón, H., \& Cervera, A. (2012). University-industry collaboration from a relationship marketing perspective: An empirical analysis in a Spanish University. Higher Education, 64(1), 85-98.

20. Freitas, I. M. B., Geuna, A., \& Rossi, F. (2013). Finding the right partners: Institutional and personal modes of governance of university-industry interactions. Research Policy, 42(1), 50-62.

21. Garcia, R., Araújo, V., Mascarini, S., Santos, E., \& Costa, A. (2013). The role of the geographical proximity and the quality of academic research to universityindustry linkages.

22. Grimpe, C., \& Hussinger, K. (2013). Formal and informal knowledge and technology transfer from academia to industry: Complementarity effects and innovation performance. Industry and innovation, 20(8), 683-700.

23. Guan, J., \& Zhao, Q. (2013). The impact of universityindustry collaboration networks on innovation in nanobiopharmaceuticals. Technological Forecasting and Social Change, 80(7), 1271-1286.

24. Hamdan, H., Yusof, F., Omar, D., Abdullah, F., Nasrudin, N., \& Abullah, I. C. (2011). University industrial linkages: relationship towards economic 
growth and development in Malaysia. World Academy of Science, Engineering and Technology, 5(10), 27-34.

25. Hansen, J. A., \& Lehmann, M. (2006). Agents of change: universities as development hubs. Journal of Cleaner Production, 14(9), 820-829.

26. Hemmert, M., Bstieler, L., \& Okamuro, H. (2014). Bridging the cultural divide: Trust formation in university-industry research collaborations in the US, Japan, and South Korea. Technovation, 34(10), 605-616.

27. Hetty van Emmerik, I. J., Schreurs, B., De Cuyper, N., Jawahar, I. M., \& Peeters, M. C. (2012). The route to employability: examining resources and the mediating role of motivation. Career Development International, 17(2), 104-119.

28. Hillage, J., \& Pollard, E. (1998). Employability: developing a framework for policy analysis. London: DfEE.

29. Hogan, R., Chamorro-Premuzic, T., \& Kaiser, R. B. (2013). Employability and career success: Bridging the gap between theory and reality. Industrial and Organizational Psychology, 6(1), 3-16.

30. Ishengoma, E., \& Vaaland, T. I. (2016). Can universityindustry linkages stimulate student employability? Education+ Training, 58(1), 18-44.

31. Batistic, S., \& Tymon, A. (2017). Networking behaviour, graduate employability: a social capital perspective. Education+ Training, 59(4), 374-388.

32. Jackson, D. (2015). Employability skill development in work-integrated learning: Barriers and best practice. Studies in Higher Education, 40(2), 350-367.

33. Jackson, D., \& Wilton, N. (2017). Perceived employability among undergraduates and the importance of career self-management, work experience and individual characteristics. Higher Education Research \& Development, 36(4), 747-762.

34. Kleibert, J. M. (2015). Industry-academe linkages in the Philippines: Embedding foreign investors, capturing institutions?. Geoforum, 59, 109-118.

35. Knight, P. T., \& Yorke, M. (2002). Employability through the curriculum. Tertiary Education \& Management, 8(4), 261-276.

36. Laguador, J. M., \& Ramos, L. R. (2014). Industrypartners' preferences for graduates: Input on curriculum development. Journal of Education and Literature, 1(1), 1-8.

37. Lind, F., Styhre, A., \& Aaboen, L. (2013). Exploring university-industry collaboration in research centres. European Journal of Innovation Management, 16(1), 7091

38. McArdle, S., Waters, L., Briscoe, J. P., \& Hall, D. T. T (2007). Employability during unemployment: Adaptability, career identity and human and social capital. Journal of vocational behavior, 71(2), 247-264.

39. Muscio, A., Quaglione, D., \& Scarpinato, M. (2012). The effects of universities' proximity to industrial districts on university-industry collaboration. China Economic Review, 23(3), 639-650.

40. Ngoma, M., \& Dithan Ntale, P. (2016). Psychological capital, career identity and graduate employability in Uganda: the mediating role of social capital. International Journal of Training and Development, 20(2), 124-139.

41. Pegg, A., Waldock, J., Hendy-Isaac, S., \& Lawton, R. (2012). Pedagogy for employability.

42. Perkmann, M., Tartari, V., McKelvey, M., Autio, E., Broström, A., D’Este, P., ... \& Krabel, S. (2013). Academic engagement and commercialisation: A review of the literature on university-industry relations. Research policy, 42(2), 423-442.

43. Ashraf, R. U., Hou, F., Kirmani, S. A. A., Ilyas, M., Zaidi, S. A. H., \& Ashraf, M. S. (2018). Student employability via university-industry linkages. Human Systems Management, 37(2), 219-232.

44. Pinto, L. H., \& Ramalheira, D. C. (2017). Perceived employability of business graduates: The effect of academic performance and extracurricular activities. Journal of Vocational Behavior, 99, 165-178.

45. Pinto, L. H., \& Ramalheira, D. C. (2017). Perceived employability of business graduates: The effect of academic performance and extracurricular activities. Journal of Vocational Behavior, 99, 165-178.

46. Plewa, C., Korff, N., Johnson, C., Macpherson, G., Baaken, T., \& Rampersad, G. C. (2013). The evolution of university-industry linkages-A framework. Journal of Engineering and Technology Management, 30(1), 21-44.

47. Ramos-Vielba, I., \& Fernández-Esquinas, M. (2012) Beneath the tip of the iceberg: Exploring the multiple forms of university-industry linkages. Higher Education, 64(2), 237-265.

48. Rothwell, A., \& Arnold, J. (2007). Self-perceived employability: development and validation of a scale. Personnel review, 36(1), 23-41.

49. Hair Jr, J. F., Hult, G. T. M., Ringle, C., \& Sarstedt, M. (2016). A primer on partial least squares structural equation modeling (PLS-SEM). Sage Publications.

50. Hair Jr, J. F., Sarstedt, M., Ringle, C. M., \& Gudergan, S. P. (2017). Advanced issues in partial least squares structural equation modeling. SAGE Publications.

51. Sutthijakra, S., \& Intarakumnerd, P. (2015). Role and capabilities of intermediaries in university-industry linkages: A case of hard disk drive industry in Thailand Science, Technology and Society, 20(2), 182-203.

52. Tomlinson, M. (2012). Graduate employability: A review of conceptual and empirical themes. Higher Education Policy, 25(4), 407-431.

53. Vaaland, T. I., Vaaland, T. I., Ishengoma, E., \& Ishengoma, E. (2016). University-industry linkages in developing countries: perceived effect on innovation Education+ Training, 58(9), 1014-1040.

54. Vaaland, T. I., Vaaland, T. I., Ishengoma, E., \& Ishengoma, E. (2016). University-industry linkages in developing countries: perceived effect on innovation. Education+ Training, 58(9), 1014-1040.

55. Yang, H., Cheung, C., \& Song, H. (2016). Enhancing the learning and employability of hospitality graduates in China. Journal of Hospitality, Leisure, Sport \& Tourism Education, 19, 85-96.

56. Yorke, M. (2006). Employability in higher education: what it is-what it is not(Vol. 1). York: Higher Education Academy 